EDITORIAL

\title{
Coronavirus, el talón de Aquiles del mundo.
}

El COVID-19 es una infección viral, que tuvo origen en un mercado mayorista en Wuhan, capital de la provincia de Hubei, China. ${ }^{1}$ Los primeros casos notificados a finales de diciembre 2019 y dada la voz de alarma por el Dr. Li Wenliang oftalmólogo al observarlos, publica que los casos tenían síntomas parecidos al SARS como son manifestación clínica de fiebre, dificultad respiratoria y en sus radiografías de tórax infiltrados pulmonares bilaterales.

El 5 de enero del 2020, la Organización Mundial de la Salud informa sobre la aparición de estos casos de neumonía sin etiología conocida, para finales de enero del 2020, la enfermedad se había esparcido por 9 países (8 en Asia y en Estados Unidos); el 12 de enero China pone a disposición de la OMS el genoma secuenciado que permitió la elaboración de test diagnósticos confiables (reacción de polimerasa en cadena) de manera rápida.

Para el 20 de febrero en Lombardia, ${ }^{2}$ se reporta el primer caso en Italia y en las siguientes 24 horas un total de 36 nuevos casos no relacionados con este, lo que inicia la epidemia en ese país y a nivel europeo. El 11 de marzo la OMS declara que el brote de Coronavirus es una pandemia.

\section{Evolución del Covid-19 en Panamá}

El 9 de marzo se confirma por laboratorio, el primer caso de COVID-19 en Panamá. Se trata de una paciente femenina de 40 años, quien ingresó al país el día 8 de marzo en horas de la tarde, procedente de Barajas España. ${ }^{3}$

El día 10 de marzo, la Ministra de Salud anuncia un total de 8 casos confirmados de COVID-19 en el país, incluyendo una defunción. Los casos, todos panameños, entre los 29 y 64 años, corresponden a las Regiones de Panamá Metro y Panamá Norte.

Se suspenden las actividades recreativas, las clases en colegios y universidades en las áreas de Panamá Metro, Norte y el distrito de San Miguelito. ${ }^{4}$

El presidente de la República, mediante resolución de gabinete número 11 del 13 de marzo de 2020, declara estado de emergencia nacional. ${ }^{5}$

Se ordena que a partir del lunes 16 de marzo el cierre de todas los establecimientos dedicados a recreación (playas, teatros, bares, etc.), el ingreso a locales comerciales se limita 50 personas y se restringe la entrada a Panamá de viajeros procedentes de Europa y Asia, exceptuando a panameños y residentes. ${ }^{6}$

\section{¿Qué sabemos del SARS-CoV-2 hasta ell momento?}

Es un virus de ARN de la familia de los Coronavirus, conocido inicialmente COVID-19 y posteriormente como SARS-CoV-2. El SARS Cov2 tiene un origen cercano al coronavirus de murciélagos con un huésped intermediario aún desconocido. La transmisión es por vía área, fómites que contaminan objetos o superficies, pero principalmente de persona a persona.

Que existen individuos asintomáticos pueden transmitir el virus y la transmisión secundaria ocurre antes de la aparición de la enfermedad, que es altamente contagioso, con un número de reproducción básico $\mathrm{R}$ de 2.5 (número de infecciones que un caso puede generar a lo lardo de su periodo infeccioso) 
El periodo de incubación promedio de 5 a 10 días, el virus permanece en las secreciones respiratorias, orina hasta 15 día y en heces hasta 5 semanas.

Que hasta el momento a nivel mundial la severidad de la infección parece no presentarse en los menores de 15 años, siendo amplio el espectro de presentación en pediatría desde asintomático hasta casos de leves a moderados y con una menor letalidad.

Pero esto no ha hecho más que comenzar y tendremos que esperar los datos que se generarán en próximos meses sobre esta enfermedad.

\section{Elizaleth Castaño \\ Dra. Elizabeth Castaño \\ Editora Jefe}

\section{Referencias}

1. Zhu N, Zhang D, Wang W et al. N Engl J Med 2020;382:727-33. DOI: 10.1056/NEJMoa2001017

2. Grasselli G, Pesenti A, Cecconi M. Critical Care Utilization for the COVID-19 Outbreak in Lombardy, Italy: Early Experience and Forecast During an Emergency Response. JAMA. 2020;323(16):1545-1546. doi:10.1001/jama.2020.4031

3. Comunicado del MINSA 9 de marzo 2020 http://www.minsa. gob.pa/noticia/panama-confirma-primer-caso-de-covid-19
4. Comunicado del MINSA 10 de marzo 2020 http://www.minsa. gob.pa/noticia/comunicado-n-2

5. Resolución de gabinete número 11 del 13 de marzo de 2020, "que declara el estado de emergencia nacional y dicta otras disposiciones".https://www.gacetaoficial.gob.pa/pdfTemp/28979_B/GacetaNo 28979b 20200313.pdf

6. Comunicado del MINSA 16 de marzo de 2020. http://www. minsa.gob.pa/noticia/comunicado-ndeg10 